Check for updates

Cite this: RSC Adv., 2017, 7, 47500

\title{
Influence of lead-free glass frit in the front contact paste on the conversion efficiency of polycrystalline silicon solar cells
}

\author{
Qian $\mathrm{Ma},{ }^{\mathrm{a}}$ Shenghua $\mathrm{Ma},{ }^{\mathrm{b}}$ Jintao Bai ${ }^{\star \mathrm{b}}$ and Hui Wang (D) *a
}

Due to the demand for a new environmentally friendly silver front conductive paste, it is imperative for silicon solar cells to use nontoxic lead-free glass frits. In the present paper, three kinds of $\mathrm{Bi}-\mathrm{Te}-\mathrm{B}-\mathrm{Si}-$ $\mathrm{P}-\mathrm{O}$ lead-free glass frits with different mass fraction ratios of $\mathrm{B}_{2} \mathrm{O}_{3} / \mathrm{SiO}_{2}(10 / 4,6 / 8$, and 2/12) were prepared by a melt cooling route. First, we investigated that the effect of those $\mathrm{B}_{2} \mathrm{O}_{3} / \mathrm{SiO}_{2}$ ratios on the transition temperature $\left(T_{\mathrm{g}}\right)$ of glass frits, and their $T_{\mathrm{g}}$ were $311{ }^{\circ} \mathrm{C}, 347^{\circ} \mathrm{C}$, and $366^{\circ} \mathrm{C}$, respectively. Then, the influence of $T_{\mathrm{g}}$ on cross-sectional microstructures of the front-silver electrodes, the $\mathrm{Ag}$ crystallites distribution on Si substrate, and electrical performance were studied. The fabricated solar cell showed the lowest series resistance $(0.0017 \Omega$ ) and the highest photoelectric conversion efficiency (18.260\%) based on the glass frit $T_{\mathrm{g}}$ of $347^{\circ} \mathrm{C}$. This is because the dense thick-film Ag grid can reduce the bulk resistance of the grid line. Besides, the glass frit with the $T_{\mathrm{g}}$ of $347{ }^{\circ} \mathrm{C}$ could control the growth and homogeneous distribution of silver crystallites in the glass layer and silicon substrate, which contributed to forming good ohmic contacts and tunneling effect with enough energy photoelectrons. The result was compared with the solar cell fabricated with a classical Pb-based glass frit with the conversion efficiency (18.230\%) using the same device configuration, which indicated the designed lead-free glass frit could be a suitable substitute for a $\mathrm{Pb}$-based glass frit for preparing environmentally friendly frontside silver paste for crystalline silicon solar cells.

Received 10th July 2017

Accepted 4th October 2017

DOI: $10.1039 / c 7 r a 07574 j$

rsc.li/rsc-advances

\section{Introduction}

Crystalline silicon solar cells have attracted remarkable attention in recent years as a promising renewable clean energy source because of their high photoelectric conversion efficiency and dependable mass production. ${ }^{1-3}$ In the industrialization of high yield production, the front-side silver conductive thick films are achieved by screen printing which is a low cost and time-effective option compared with other metallization techniques and rapid thermal processing: ${ }^{4-7}$ Generally, the main constituents of silver conductive paste are as follows: silver powders, glass frits, and resin binder. ${ }^{8-10}$ Optimizing the glass frits of the Ag paste can help achieve good-quality thick-film ohmic contacts. ${ }^{11}$ During the rapid sintering of the Ag paste, the glass frit merely holds $2-5 \mathrm{wt} \%$ as a binder and has

${ }^{a}$ Key Laboratory of Synthetic and Natural Functional Molecule Chemistry (Ministry of Education), College of Chemistry \& Materials Science, Northwest University, Xi'an 710069, P. R. China. E-mail: huiwang@nwu.edu.cn; Fax: +86 298830 3798; Tel: +862988363115

${ }^{b}$ National Key Laboratory of Photoelectric Technology and Functional Materials (Culture Base), National Photoelectric Technology and Functional Materials \& Application of International Science and Technology Cooperation Base, Institute of Photonics \& Photon-Technology, Northwest University, Xi'an 710069, P. R. China. E-mail: jintaobai@sina.cn; baijt@nwu.edu.cn; Fax: +86 298830 3798; Tel: +86 29 88303877 a significant effect on the front-side metallization contact formation and forming an electrical contact between the $\mathrm{Ag}$ electrode and $\mathrm{Si}$ wafer. Through corrupting antireflection coating (ARC) on the surface of the Si wafer, Ag crystallites will grow on the silicon emitter surface. What is more, glass frit is crucial for the adhesion strength of $\mathrm{Ag}$ electrode to Si wafer and total resistance of the electrode. ${ }^{\mathbf{1 2 - 1 7}}$

Currently, Pb-based glass is almost widely used to the industry on account of excellent electrical and mechanical properties. However, the use of lead is harmful to people health and the environment. With the attention to environmental pollution and global climate change, the preparation and research of the lead-free silver paste had attracted wide attention. In previous studies, the use of lead-free glass frit in $\mathrm{Ag}$ paste has been investigated. ${ }^{18-22}$ Jeon et $a l .{ }^{23}$ reported the influence of particle size of lead-free glass frit in the front contact paste on the conversion efficiency of silicon solar cell. When the glass frit with a small mean particle size was used, the silver paste had a higher $\mathrm{FF}$ and $E_{\mathrm{ff}}$. Kim et al. ${ }^{24}$ prepared the $\mathrm{Bi}-$ $\mathrm{Zn}-\mathrm{Si}-\mathrm{B}-\mathrm{Al}-\mathrm{Ca}-\mathrm{O}$ glass frit with spherical shape and submicron size, obtained glass frit improve the sintering characteristics of the silver powders at $700{ }^{\circ} \mathrm{C}$ to form the silver conducting film with dense structure and high adhesion strength to the $\mathrm{Si}$ substrate. Che et $a .^{2}{ }^{2}$ reported that nanosized glass frit powders showed an excellent wetting behavior and etching effects on 
$\operatorname{SiN}_{x}$ coating and silicon compared to micrometer-sized frits. There was a glass layer at the interface between the Ag grids and $\mathrm{Si}$ emitter for $\mathrm{Pb}$ - or Bi-based glass, however, Jiang et al. ${ }^{25}$ developed a new $\mathrm{Pb}$-free $\mathrm{Ag}$ paste with a $\mathrm{SnO}-\mathrm{P}_{2} \mathrm{O}_{5}$ glass frit that revealed no glass layer at the interface between the Ag grids and $\mathrm{Si}$ emitter for front contact electrodes of crystalline silicon solar cells. So far, the actual electrical contact formation pathway remained barely understood, Fields J. D. et al. ${ }^{26}$ believed that achieving optimal firing conditions to minimize contact resistance, and to develop new pastes with alternative materials (that is, earth-abundant and non-toxic), required a detailed understanding of the contact formation process by situ X-ray diffraction (XRD). The $T_{\mathrm{g}}$ of the glass frit is one of the most significant properties that determine the glass behavior. Therefore, it is essential to prepare the glass frit with appropriate $T_{\mathrm{g}}$ for front contact silver paste to obtain good ohmic contact.

In order to better understand the function of $T_{\mathrm{g}}$ of the glass frit, we focused on the preparation of three lead-free glass frits with different $T_{\mathrm{g}}$ by changing $\mathrm{B}_{2} \mathrm{O}_{3} / \mathrm{SiO}_{2}$ mass fraction ratios to understand how to form better contact quality. The surface morphology of the shattered glass frit, the cross-sectional microstructures of the front-silver electrodes and the Ag crystallites distribution on Si substrate were observed by SEM, the size and quantity of $\mathrm{Ag}$ crystallites were affected by $T_{\mathrm{g}}$, which influenced the quality of interfacial structure and the electrical performance of silicon solar cell. Finally, a simple schematic, which explained the size of $\mathrm{Ag}$ crystallites and the dissolution of silver particles, was designed based on final results.

\section{Experimental}

\section{Materials}

All the raw materials used for the preparation of glass frit were shown below, $\mathrm{Bi}_{2} \mathrm{O}_{3}\left(\geq 99.5 \%\right.$, Zhengzhou PainI), $\mathrm{TeO}_{2}$ ( $\geq 99.0 \%$, Tianjin Yaohua), $\mathrm{HBO}_{3}(\geq 99.5 \%$, Tianjin Fuchen), $\mathrm{SiO}_{2}\left(\geq 99.9 \%\right.$, Sinopharm Chemical Reagent Co., Ltd) and $\mathrm{P}_{2} \mathrm{O}_{5}$ ( $\geq 98.0 \%$, Tianjin Kermel Chemical Reagent Co., Ltd.), the Pbbased glass frit have been purchased from Korea.

\section{Preparation of glass frit powders}

The compositions of $\mathrm{Bi}-\mathrm{Te}-\mathrm{B}-\mathrm{Si}-\mathrm{P}-\mathrm{O}$ glass frit with different $\mathrm{B}_{2} \mathrm{O}_{3} / \mathrm{SiO}_{2}$ mass fraction ratios were shown in Table 1 . Bi-Te-B$\mathrm{Si}-\mathrm{P}-\mathrm{O}$ glass frit for the front contact paste in polycrystalline silicon solar cells were prepared by melt cooling route. All metallic oxides were mixed uniformly in an agate mortar for $30 \mathrm{~min}$, then were heated at $1200{ }^{\circ} \mathrm{C}$ for $30 \mathrm{~min}$ at this temperature in an aluminum crucible at a heating rate of $10^{\circ} \mathrm{C} \mathrm{min}^{-1}$ in a muffle furnace. The melt was cooled quickly to room temperature by pouring the melt into the deionized water. Subsequently, the Bi-Te-B-Si-P-O glass frits with $D_{50}$ of $0.5-2 \mu \mathrm{m}$ were obtained prior to further use regardless of the glass composition by using a air pulverizer (Mianyang Liuneng Powder Equipment Co., Ltd., SB100A/20A, China). The average particle sizes and size distributions were measured using a laser size distribution analyzer (BT-9300-H, Dandong City Baxter Instrument Co., Ltd.). These three kinds of glass frits were named as GF-1, GF-2, and GF-3, respectively.

\section{Preparation of organic vehicle}

The uniform stoichiometric mixed solvents that butyl carbitol, terpineol, $N$-butyl butyrate and tributyl citrate were added into a three-necked flask. Then a certain quality of thickener (EC), thixotropic agents, surfactant (sorbitan trioleate), and bonding agent (silane coupling agent KH-570) were added sequentially. The materials were mechanically stirred around $90-110{ }^{\circ} \mathrm{C}$ in a oil bath with stirring for $2 \mathrm{~h}$ and then cooled naturally to room temperature after complete reaction.

\section{Preparation of glass paste}

The glass paste was prepared to observe the wetting behavior and etching effect of the glass frit on ARC and the reaction with silicon wafer. Subsequently, by mixing $83 \mathrm{wt} \%$ the as-prepared glass frit powders and $17 \mathrm{wt} \%$ organic vehicle to prepare test paste. Then the glass paste was deposited on silicon substrate with ARC by screen printing. Next the sample was fired in a tube furnace at $800{ }^{\circ} \mathrm{C}$ for $10 \mathrm{~min}$.

\section{Screen printing Ag paste}

In this experiment, optimum particle size of silver (purchased from Xi'an Jingsheng Light Technology Co., Ltd., China), Bi-Te$\mathrm{B}-\mathrm{Si}-\mathrm{P}-\mathrm{O}$ glass frit, and the organic vehicle were homogeneously mixed to prepare silver paste. The semi-finished product went through three-roll grinding machine (Puhler, PTR65C) for several times with the shear gap parameters varied from large to small. Different Ag pastes with different glass frits were prepared (denoted as PS1, PS2, and PS3). For comparison, an additional reference silver paste was prepared by mixing the same silver particles, classical Pb-based glass frit and same organic vehicle, denoted as PS4. Then paste was printed on a multi-crystalline Si wafers with area of $156 \times 156 \mathrm{~mm}^{2}$, thickness of $200 \mu \mathrm{m}$, and sheet resistivity of $80 \Omega \square^{-1}$. The sizes of complex network meshes used were 360 meshes. The thickness of emulsion was $15 \mu \mathrm{m}$. The line-diameter and line-width of pattern was $16 \mu \mathrm{m}$, $36-38 \mu \mathrm{m}$, respectively. Subsequently, the wafers were dried in

Table 1 Experimental compositions of $\mathrm{Bi}-\mathrm{Te}-\mathrm{B}-\mathrm{Si}-\mathrm{P}-\mathrm{O}$ system glass frits (wt\%)

\begin{tabular}{|c|c|c|c|c|c|c|c|c|}
\hline GF-1 & 32.4 & 40.6 & 10 & 4 & 2.5 & 10.5 & 100 & 311 \\
\hline GF-3 & 32.4 & 40.6 & 2 & 12 & 2.5 & 10.5 & 100 & 366 \\
\hline
\end{tabular}


an oven at $100{ }^{\circ} \mathrm{C}$ for $30 \mathrm{~min}$, the printed paste was fired in a tube furnace at $800{ }^{\circ} \mathrm{C}$ at a belt speed of 235 inch per min, $5969 \mathrm{~mm} \mathrm{~min}^{-1}$ for $3 \mathrm{~min}$ to obtain the $\mathrm{Ag}$ electrode.

\section{Measurements}

The amorphous state of as-prepared glass frits were investigated with an X-ray diffractometer (XRD, D/Max-3C, Rigaku, Japan) using $\mathrm{Cu} \mathrm{K}_{\alpha}$ radiation. The glass transition temperature $\left(T_{\mathrm{g}}\right)$ of different glass frit powers were recorded by a thermogravimetric analyzer and Differential Scanning Calorimeter (Netzch TGA/DSC) at the heating rate of $20 \mathrm{~K} \mathrm{~min}^{-1}$. The infrared spectra were recorded with an FT-IR spectrometer (Nicolet NEXU S670). The surface morphologies of the shattered glass frit and the cross-sectional microstructures of the frontsilver electrodes were observed by scanning electron microscopy (SEM) (Quanta 400 FEG instrument, Oxford INCA 35 detector, $25 \mathrm{kV}$ ). The $3 \mathrm{D}$ morphology and aspect ratio of the electrode was measured by 3D digital microscope (QUESTAR, $\mathrm{RH}-2000)$. The photoelectric property of polycrystalline silicon solar cells were studied using an EKO I-V Tracer under standard testing condition (STC): solar radiation of $1000 \mathrm{~W} \mathrm{~m}^{-2}$ at $25{ }^{\circ} \mathrm{C}$.

Chemical etching was used to obtain the surface morphology of the cells, which usually included two steps: (a) aqua regia ( $\mathrm{HCl}$ $32 \%+\mathrm{HNO}_{3} 65 \%, 3: 1, t=1 \mathrm{~h}$ ) etches the silver from the finger bulk; (b) $3 \% \mathrm{HF}$ solution ( $t=10 \mathrm{~min}$ ) etches the glass layer at room temperature, leaving the Ag-crystallites grown in the emitter.

\section{Results and discussion}

\section{The morphology and microstructure $\mathrm{Bi}-\mathrm{Te}-\mathrm{B}-\mathrm{Si}-\mathrm{P}-\mathrm{O}$ glass} frit

$\mathrm{Bi}-\mathrm{Te}-\mathrm{B}-\mathrm{Si}-\mathrm{P}-\mathrm{O}$ glass frits were prepared by melt cooling route. As shown in Fig. 1a-d, all metallic oxides were mixed uniformly (1a), melted (1b), quenched (1c) and shattered (1d). Fig. 1e showed the morphology of the glass frit. In order to study the microstructure, the XRD patterns of the $\mathrm{Bi}-\mathrm{Te}-\mathrm{B}-\mathrm{Si}-\mathrm{P}-\mathrm{O}$ glass frit powders were exhibited in Fig. 2 . As can be seen from the figure, without any sharp peaks, only broad peak can be found at around $28^{\circ}$, which indicated that glass frit powders were amorphous, without crystal precipitation.

\section{The structure analysis and thermal properties of $\mathrm{Bi}-\mathrm{Te}-\mathrm{B}-\mathrm{Si}-$} P-O glass frit

The glass frit IR spectra were shown in Fig. 3. Although $\mathrm{B}_{2} \mathrm{O}_{3}$ has subtle changes, the samples showed analogical absorption

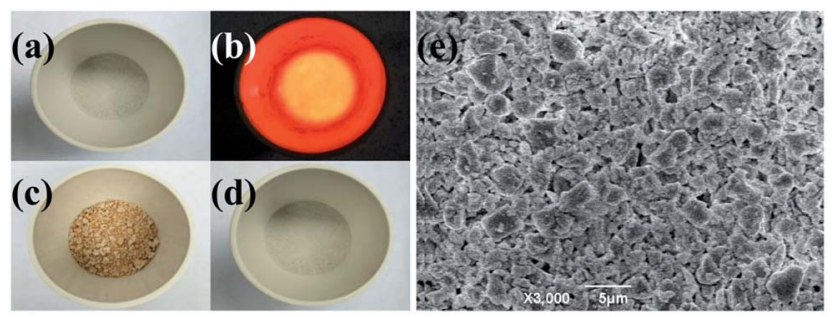

Fig. 1 The simple flow chart and SEM micrographs of $\mathrm{Bi}-\mathrm{Te}-\mathrm{B}-\mathrm{Si}-\mathrm{P}-\mathrm{O}$ glass frit prepared by the traditional melting route.

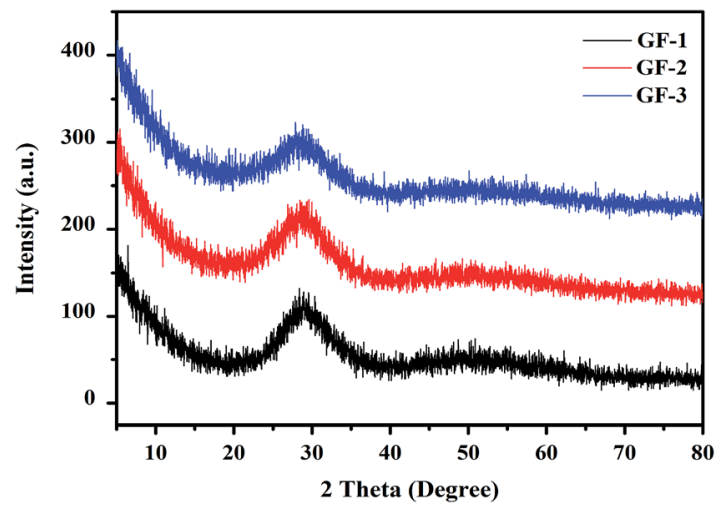

Fig. 2 XRD pattern of different $\mathrm{Bi}-\mathrm{Te}-\mathrm{B}-\mathrm{Si}-\mathrm{P}-\mathrm{O}$ glass frit.

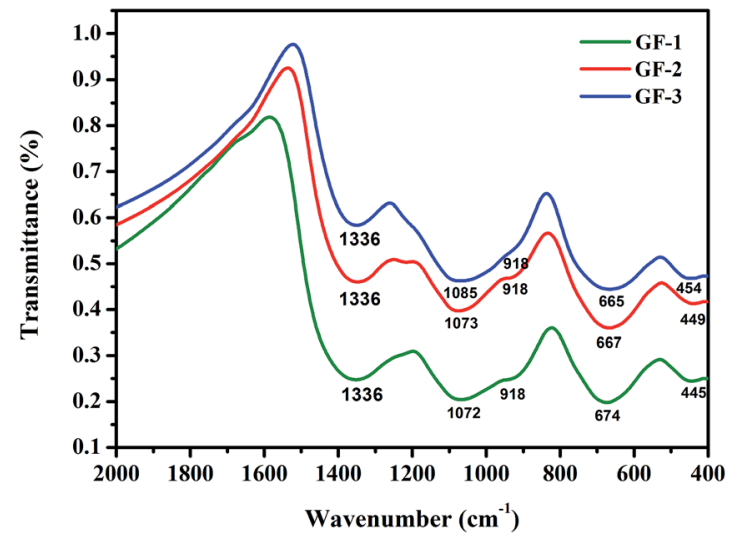

Fig. 3 The infrared spectra of $\mathrm{Bi}-\mathrm{Te}-\mathrm{B}-\mathrm{Si}-\mathrm{P}-\mathrm{O}$ glass frit powders.

bands. The vibration types of the investigated glasses were summarized in Table 2 . By analyzing the spectra, the bands at about $450 \mathrm{~cm}^{-1}$ are ascribed to the $\mathrm{Bi}-\mathrm{O}-\mathrm{Bi}$ in the $\left[\mathrm{BiO}_{6}\right]$ octahedral units ${ }^{27-29}$ and the $\mathrm{Si}-\mathrm{O}$ bend vibration. ${ }^{30}$ The infrared spectra in the range of about $680 \mathrm{~cm}^{-1}$ is due to the bending vibration of $\mathrm{B}-\mathrm{O}-\mathrm{B}$ in $\left[\mathrm{BO}_{3}\right]$ triangles. ${ }^{31,32}$ The bands at around $918 \mathrm{~cm}^{-1}$ may be due to the symmetric stretching vibrations of $\left[\mathrm{BiO}_{3}\right]$ and $\left[\mathrm{BiO}_{6}\right]$ polyhedral, ${ }^{29}$ it can be deduced that $\left[\mathrm{BiO}_{3}\right]$ trigonal and $\left[\mathrm{BiO}_{6}\right]$ octahedral units constitute the bismuthate structure of studied glasses. The wide spectral at around $1070 \mathrm{~cm}^{-1}$ is due to the $\mathrm{B}-\mathrm{O}-\mathrm{B}$ stretch vibration in $\left[\mathrm{BO}_{4}\right]$. The result indicates that the addition of $\mathrm{Bi}_{2} \mathrm{O}_{3}$ to glass frit maybe cause a effective conversion of $\left[\mathrm{BO}_{3}\right]$ units to $\left[\mathrm{BO}_{4}\right]$ units. ${ }^{33}$ The bands ranging from $1320 \mathrm{~cm}^{-1}$ to $1340 \mathrm{~cm}^{-1}$ are assigned to the $\mathrm{B}-\mathrm{O}$ bonds in $\mathrm{BO}_{3} .^{29}$

The DSC curves of GF-1, GF-2, and GF-3 samples were showed in Fig. 4. The onset point of the first large peak represented the $T_{\mathrm{g}}$ of glass frit, which were summarized in Table 1. The range of $T_{\mathrm{g}}$ for glass frits was changed from $311^{\circ} \mathrm{C}$ to $366^{\circ} \mathrm{C}$ by decreasing the content of $\mathrm{B}_{2} \mathrm{O}_{3}$. The data in Table 1 and Fig. 3 show that, by changing $\mathrm{B}_{2} \mathrm{O}_{3} / \mathrm{SiO}_{2}$ ratio, the $T_{\mathrm{g}}$ of glass frit gradually increased as decreasing the content of $\mathrm{B}_{2} \mathrm{O}_{3}$. The major reason is that, with increasing the content of $\mathrm{B}_{2} \mathrm{O}_{3},\left[\mathrm{BO}_{3}\right]$ gradually was replaced. As $\left[\mathrm{BO}_{3}\right]$ has relatively poor stability, it is easy to be destroyed, which caused the reduction of the $T_{\mathrm{g}}$ of the 
Table 2 Vibration types of different IR wave numbers

Wave number

$\left(\mathrm{cm}^{-1}\right) \quad$ Vibration types

\begin{tabular}{|c|c|}
\hline $420-520$ & $\mathrm{Bi}-\mathrm{O}-\mathrm{Bi}$ in the $\left[\mathrm{BiO}_{6}\right]$ octahedral units ${ }^{27-29}$ \\
\hline $40-$ & Bridging oxygen bending in the Si network ${ }^{30}$ \\
\hline $80-$ & Bending vibration of $\mathrm{B}-\mathrm{O}-\mathrm{B}$ in $\left[\mathrm{BO}_{3}\right]$ triangles $^{28,29}$ \\
\hline 00 & $\begin{array}{l}\text { Symmetric stretching vibrations of }\left[\mathrm{BiO}_{3}\right] \text { and }\left[\mathrm{BiO}_{6}\right. \\
\text { polyhedral }^{29}\end{array}$ \\
\hline 080 & $\begin{array}{l}\text { Stretching vibration of }\left[\mathrm{BO}_{4}\right] \text { tetrahedron }^{33} \\
{\left[\mathrm{BO}_{3}\right] \text { vibration }}\end{array}$ \\
\hline
\end{tabular}

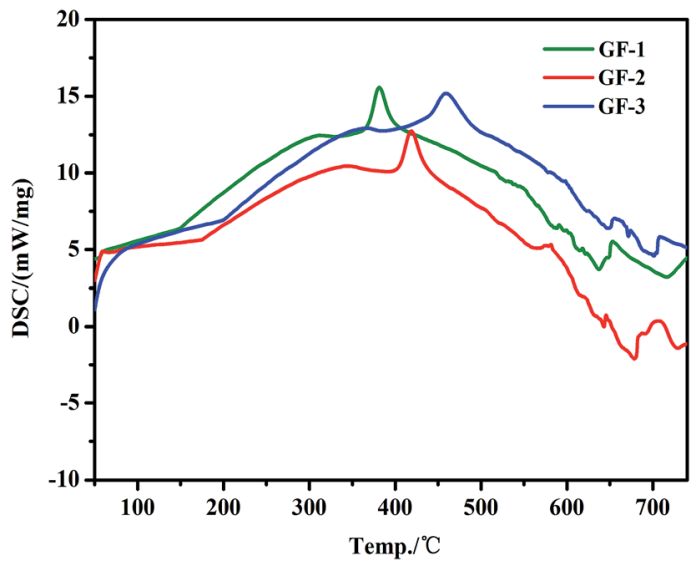

Fig. 4 DSC curve of the $\mathrm{Bi}-\mathrm{Te}-\mathrm{B}-\mathrm{Si}-\mathrm{P}-\mathrm{O}$ glass frit.

glass frits. However, expansion coefficient of the glass frit will increase with $\mathrm{B}_{2} \mathrm{O}_{3}$ massive introduction, which lead to not matching with expansion coefficient of the wafer and wafer burst ultimately.

\section{The effect of properties of glass frit on etching ARC and Si substrate}

The cross-section SEM images of the glass fingers deposited by screen printing on silicon wafer with $\mathrm{SiN}_{x}$ coating are shown in Fig. 5 (denoted as GP1, GP2, and GP3). During the rapid sintering of the glass paste, the glass frit begin getting fluid phase to wet and corrupt ARC on the surface of the Si wafer, then a few pores and small precipitates were observed in Fig. 5, followed by etching on silicon wafer, which indicated that the glass frit showed excellent wetting behavior and etching effect on $\operatorname{SiN}_{x}$ coating and silicon substrate. The small precipitates should be $\mathrm{Bi}$ and few pores should generate $\mathrm{N}_{2}$, which can be explained by the following deduced redox reactions ${ }^{2,7}$ :

$$
\begin{gathered}
2 \mathrm{Bi}_{2} \mathrm{O}_{3 \text {-glass }}+3 \mathrm{SiN}_{x} \rightarrow 4 \mathrm{Bi}+3 \mathrm{SiO}_{2}+3 x / 2 \mathrm{~N}_{2} \\
2 \mathrm{Bi}_{2} \mathrm{O}_{3 \text {-glass }}+3 \mathrm{Si} \rightarrow 4 \mathrm{Bi}+3 \mathrm{SiO}_{2}
\end{gathered}
$$

As showed in Fig. 5, many large precipitates and pores could be observed in glass paste (Fig. 5a), probably due to the higher content of $\mathrm{B}_{2} \mathrm{O}_{3}$, during sintering, the viscosity of glass frit with

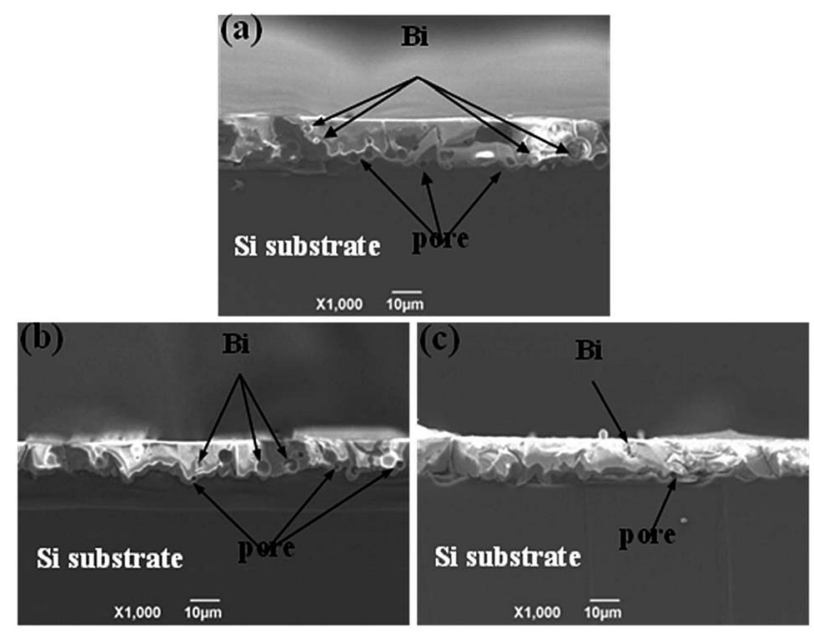

Fig. 5 Cross-section SEM images of the glass fingers deposited on silicon wafer with $\mathrm{SiN}_{x}$ coating by screen printing: (a) GP1; (b) GP2; (c) GP3.

lower $T_{\mathrm{g}}$ decreases dramatically, which reacted with $\operatorname{SiN}_{x}$ coating and silicon substrate for a very long time, contributing to the formation of large pores. A few holes could be noticed using the GF-3 sample (Fig. 5c), as $T_{\mathrm{g}}$ of GF-3 was higher, the glass frit not easily wetted $\mathrm{SiN}_{x}$ coating, as a result, the glass frit not corrupt $\mathrm{SiN}_{x}$ coating completely, which in turn lead to poor contact with Si substrate. The glass frit using the GF-2 sample with moderate $T_{\mathrm{g}}$ (Fig. 5b) relatively glossy and denser. Finally, the glass frit etched the $\mathrm{SiN}_{x}$ layer and formed compact contact with Si substrate. In summary, the content of $\mathrm{B}_{2} \mathrm{O}_{3}$ affected the $T_{\mathrm{g}}$ of glass frit, and then influence on etching $\operatorname{SiN}_{x}$ coating and Si substrate.

\section{The effect of the $T_{\mathrm{g}}$ on the morphology of $\mathrm{Ag}$ electrode}

The $T_{\mathrm{g}}$ of the glass frit is crucial for the contact ohmicity of the thick-film Ag grid. Fig. 6 shows the surface morphology and cross-sectional SEM images of three silver electrode after firing to further understand the effect of $T_{\mathrm{g}}$ on the contact formation using GF-1, GF-2 and GF-3, respectively (denoted as SP1, SP2 and SP3). During fast sintering stage, lower $T_{\mathrm{g}}$ of the lead-free glass powder could be melted in a short time, liquid glass powder along the gap between the silver flow to the silicon surface to play the role of corroding anti-reflective film, result in formation of many holes (Fig. 6a). However, the lead-free glass powder do not completely melt with higher $T_{\mathrm{g}}$, silver particles could not well-distributed and silver particles are still very obvious (Fig. 6c). In comparison to the SP2 paste (Fig. 6b), the surface morphology of silver electrode after firing is relatively compact and denser. Therefore, as an inorganic binder, the $T_{\mathrm{g}}$ of the glass frit affects largely the sintering quality of silver metal electrode and the metallization of contact formation.

Through the observation of cross-section images (d, e and f), in the SEM image (Fig. 6d), the glass frit with lower $T_{\mathrm{g}}$ generally results in a thicker glass layer between the $\mathrm{Ag}$ bulk of the grid and the Si emitter, which could cause higher contact resistance. SEM image (Fig. 6f) shows that the bulk of the Ag grid and the Si 

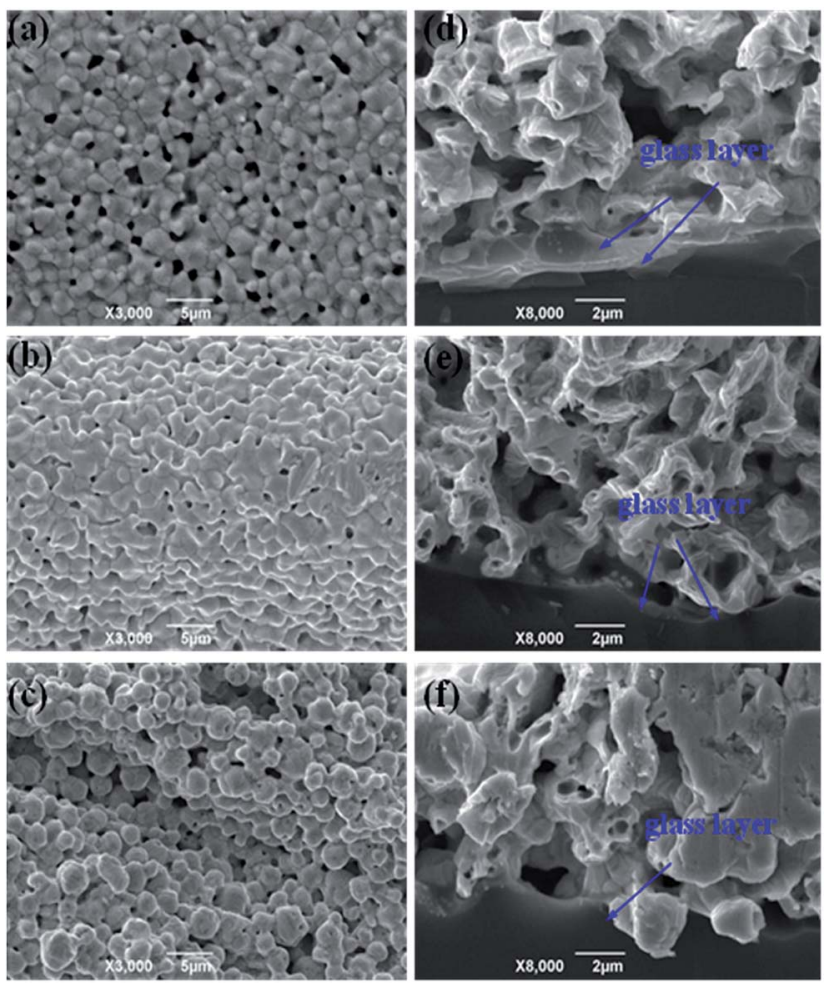

Fig. 6 The surface morphology and cross-sectional SEM images of three silver electrode after firing: top view $(a-c)$, cross-section images $(d-f)$.

emitter surface are separated by a thinner glass layer. Nevertheless, the high $T_{\mathrm{g}}$ glass frits can not easily wetted $\mathrm{SiN}_{x}$ coating and have insufficient time to wet the Si surface because of the quite short time of during fast sintering stage, which causes eqn (1) and (2) can not timely reaction, because the sinter temperature must be high adequately to melt the glass frit during the firing cycle. SEM image (Fig. 6e) shows uniform and quasicontinuous glass layer. The thickness of glass layer should be suitable for the derivation of photoelectrons with enough energy, which leads to tunneling effect. ${ }^{34}$ Therefore, the solar cells could achieve good ohmic contact and a lower contact resistance. ${ }^{35,36}$

\section{The effect of the $T_{\mathrm{g}}$ on $\mathrm{Ag}$ crystallites grown $\mathrm{Si}$ substrate}

The effects of the $T_{\mathrm{g}}$ on the Ag crystallites distribution in the glass layer and Si substrate were investigated and explored. As shown in Fig. 7, the glass frit and Ag bulks were selectively etched-off before taking the images using a sequence of aqua regia for etching the $\mathrm{Ag}$ bulks, followed by $3 \% \mathrm{HF}$ solution for etching the glass frit to expose the $\mathrm{Ag}$ particles and $\mathrm{Ag}$ crystallites in the Si substrate. The dissolved $\mathrm{Ag}$ in the glass layer was deposited on the silicon surface, during cooling, Ag crystallites were formed on the Si substrate surface. Fig. 7 shows that the glass frit with lower $T_{\mathrm{g}}$ (Fig. 7a) led to larger and more frequent distribution of Ag crystallites compared with the glass frit with higher $T_{\mathrm{g}}$ (Fig. 7c). The glass frit with lower $T_{\mathrm{g}}$ earlier started to flow during the firing cycle, which allows the glass to interact

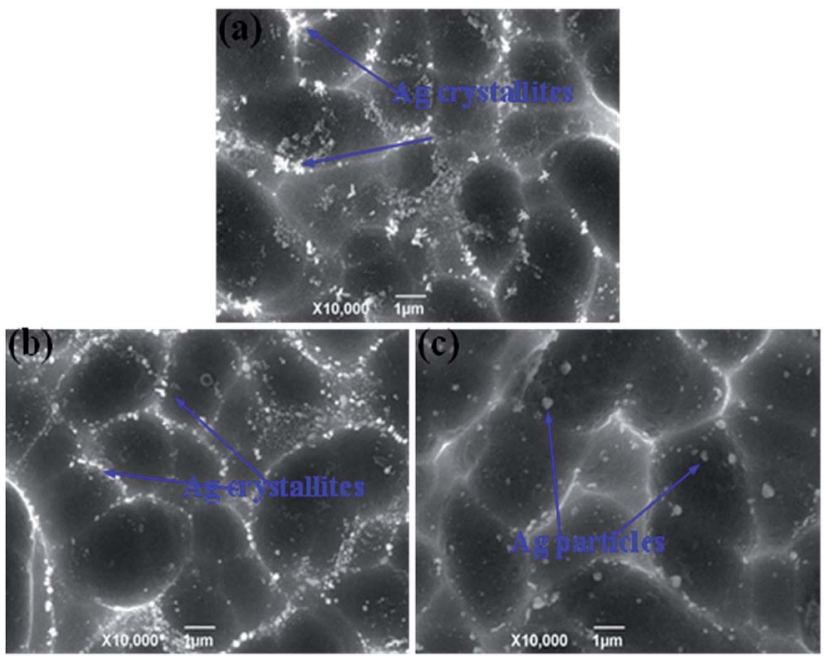

Fig. 7 Top SEM images of the crystalline Si solar cells that have been chemically etched: (a) $T_{\mathrm{g}}=311^{\circ} \mathrm{C}$, (b) $T_{\mathrm{g}}=347^{\circ} \mathrm{C}$, and (c) $T_{\mathrm{g}}=366^{\circ} \mathrm{C}$.

with the Ag particles for a longer time during firing, resulting in dissolving more Ag particles before completely sintering. Dissolved Ag particles would preferentially nucleate into Ag crystallites, which would possibly break-down the $\mathrm{p}-\mathrm{n}$ junction and lead to lower electric properties, ${ }^{37}$ however, Ag particles (Fig. 7c) did not have sufficient time for nucleation. In comparison to Fig. 7b, Ag crystallites on the Si substrate surface were uniform and moderate size. In addition, more homogeneous Ag crystallites on the silicon surface could help in forming good ohmic contacts. A simple schematic illustration for the formation was given in Fig. 8.

The electrical performance parameters of solar cells that have been printed using silver pastes of PS1, PS2, PS3 and PS4 (denoted as SC1, SC2, SC3 and SC4) were shown in Table 3. The fabricated solar cell (SC2) based on the GF-2 glass frit $\left(T_{\mathrm{g}}=347{ }^{\circ} \mathrm{C}\right)$ provided with the highest conversion efficiency and $\mathrm{FF}$, in summary, which could be lead to the $T_{\mathrm{g}}$ of glass frit, attributing to the effect on the front metallization contact of thick-film metal grid. Therefore, the $T_{\mathrm{g}}$ of glass frit is either too high or too low for the front contact paste of polycrystalline silicon solar cells, should be controlled in a optimum range. Besides, the fabricated solar cell (SC2) showed higher electrical conversion efficiency when compared with SC4 using classical Pb-based glass frit, which could be explained by comparison of the series resistance $\left(R_{\mathrm{S}}\right)$. The lower conversion efficiency should be due to the poor $R_{\mathrm{s}}$. Owing to all other factors being equal except for the inorganic binder source, this degradation may due to the poor metallization contact. Therefore, the result indicated the designed lead-free glass frit could be a suitable substitute for $\mathrm{Pb}$-based glass frit for preparing environmentally friendly frontside silver paste for crystalline silicon solar cells. These results are similar to the report by Che et al. ${ }^{7}$ Fig. 9 shows microscopic pictures of a conductive silver line printed on a textured multicrystalline silicon surface using the GF-2 glass frit. As can be seen from the graph, the front electrode grid line smooth and homogeneous, in addition, which showed a appropriate $3 \mathrm{D}$ morphology and aspect ratio. 


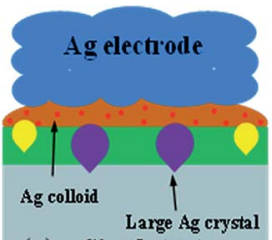

(a) Si substrate

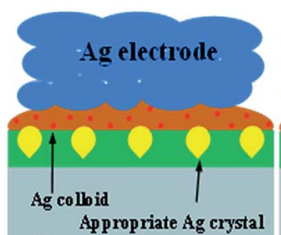

(b) Si substrate

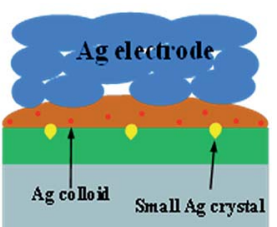

(c) Si substrate

Fig. 8 Schematic diagram of the effect of $T_{\mathrm{g}}$ from low to high on the solar cells: (a) $T_{\mathrm{g}}=311^{\circ} \mathrm{C}$, (b) $T_{\mathrm{g}}=347^{\circ} \mathrm{C}$, and (c) $T_{\mathrm{g}}=366^{\circ} \mathrm{C}$.

Table 3 Electrical performance parameters of solar cells SC1, SC2, and SC3

\begin{tabular}{lllllll}
\hline & \multicolumn{6}{c}{ Electrical performance parameters } \\
\cline { 3 - 7 } Paste & Cell & $V_{\text {oc }}(\mathrm{V})$ & $I_{\text {sc }}(\mathrm{A})$ & $R_{\mathrm{S}}(\Omega)$ & $\mathrm{FF}(\%)$ & $E_{\mathrm{ff}}(\%)$ \\
\hline SP1 & SC1 & 0.629 & 8.928 & 0.0019 & 79.425 & 18.146 \\
SP2 & SC2 & 0.631 & 8.937 & 0.0017 & 79.584 & 18.260 \\
SP3 & SC3 & 0.625 & 8.902 & 0.0021 & 78.808 & 18.012 \\
SP4 & SC3 & 0.634 & 8.899 & 0.0018 & 79.526 & 18.230 \\
& & & & & & \\
\hline
\end{tabular}
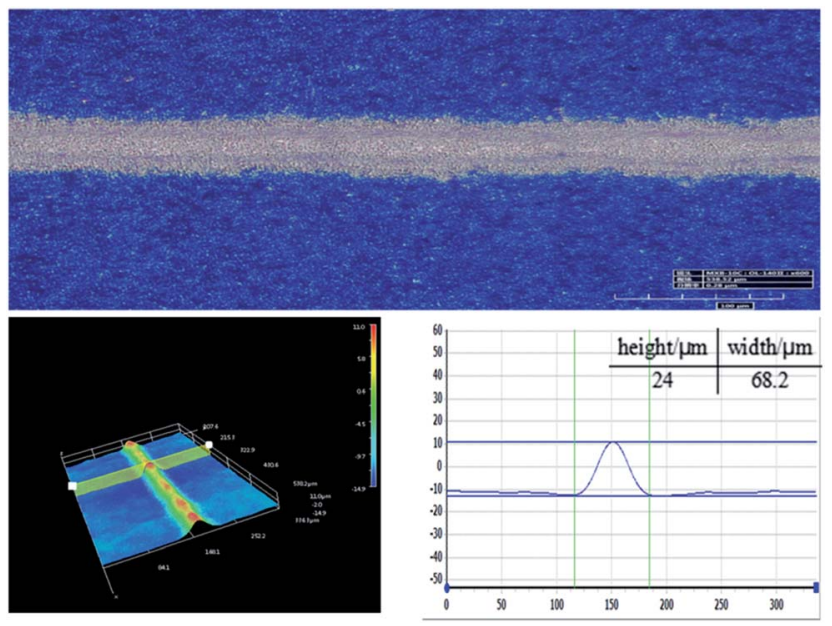

Fig. 9 3D micrographs of the front electrode grid line of SC2.

\section{Conclusions}

An environmentally friendly $\mathrm{Bi}-\mathrm{Te}-\mathrm{B}-\mathrm{Si}-\mathrm{P}-\mathrm{O}$ lead-free glass frit with different transition temperature $\left(T_{\mathrm{g}}\right)$ by changing $\mathrm{B}_{2} \mathrm{O}_{3} /$ $\mathrm{SiO}_{2}$ mass fraction ratios for the front contact paste in polycrystalline silicon solar cells were prepared by melt cooling route. The $T_{\mathrm{g}}$ of the glass frit is one of the most significant properties that determine the glass behavior, which would effect on the Ag-Si contact of thick-film silver grid. The crosssectional microstructures of the front-silver electrodes and the $\mathrm{Ag}$ crystallites distribution on Si substrate were observed by SEM, through SEM observations, the glass frit with appropriate $T_{\mathrm{g}}\left(347^{\circ} \mathrm{C}\right)$ could control the growth and homogeneous distribution of silver crystallites in the glass layer and silicon substrate, which contributed to form good ohmic contacts and tunneling effect with enough energy photoelectrons. Therefore, the $T_{\mathrm{g}}$ of glass frit is either too high or too low for the front contact paste of polycrystalline silicon solar cells, should be controlled in a optimum range. Through screen printing technology, which showed excellent aspect ratio by $3 \mathrm{D}$ digital microscope with GF-2 glass frit. The fabricated solar cell (SC2) based on the GF-2 glass frit $\left(T_{\mathrm{g}}=347^{\circ} \mathrm{C}\right)$ provided with the highest conversion efficiency $(18.260 \%)$ and the lowest series resistance $(0.0017 \Omega)$. The result was compared with the solar cell fabricated with classical Pb-based glass frit with the conversion efficiency (18.230\%) using the same device configuration, which indicated the designed lead-free glass frit could be a suitable substitute for Pb-based glass frit for preparing environmentally friendly front-side silver paste for crystalline silicon solar cells.

\section{Conflicts of interest}

There are no conflicts to declare.

\section{Acknowledgements}

The authors are grateful to the financial supports of the National Hi-Tech Research and Development Program (863) Key Project of China (No. 2012AA050301-SQ2011GX01D01292), Key Science and Technology Innovation Team Project of Natural Science Foundation of Shaanxi Province (2017KCT-0) and Xi'an Industrial Technology Innovation Project-technology transfer promoting program (No. CXY1412, CX1242 and CXY1511 (9)). This work was also supported by Key Project of Industrial Science and Technology of Shaanxi Province (No. 2016GY-090 and 2016GY-196).

\section{Notes and references}

1 G. Zheng, Y. Tai, H. Wang and J. Bai, J. Mater. Sci.: Mater. Electron., 2014, 25, 3779-3786.

2 Q. Che, H. Yang, L. Lu and Y. Wang, Appl. Energy, 2013, 112, 657-662.

3 F. Sarhaddi, S. Farahat, H. Ajam, A. Behzadmehr and M. M. Adeli, Appl. Energy, 2010, 87, 2328-2339.

4 D. Erath, A. Filipović, M. Retzlaff, A. K. Goetz, F. Clement, D. Biro and R. Preu, Sol. Energy Mater. Sol. Cells, 2010, 94, 57-61.

5 R. J. S. Young and A. F. Carroll, Advances in front-side thick film metallisation for silicon solar cells, in Proc. 16th EC PVSEC, Glasgow, Great Britain, 2000, p. VD3.63.

6 J. Qin, W. Zhang, S. Bai and Z. Liu, Appl. Surf. Sci., 2016, 376, 52-61.

7 Q. Che, H. Yang, L. Lu and Y. Wang, J. Alloys Compd., 2013, 549, 221-225.

8 Z. Liu, X. Qi and H. Wang, Adv. Powder Technol., 2012, 23, 250-255.

9 J. Zhou, N. Xu, H. Yang and Q. Zhang, Procedia Eng., 2014, 94, $1-5$. 
10 S. Rane, T. Seth, G. Phatak, D. Amalnerkar and M. Ghatpande, J. Mater. Sci.: Mater. Electron., 2004, 15, 103-106.

11 C. Ballif, D. Huljić, G. Willeke and A. Hessler-Wyser, Appl. Phys. Lett., 2003, 82, 1878-1880.

12 J.-T. Tsai and S.-T. Lin, J. Alloys Compd., 2013, 548, 105-109.

13 Y. Zhang, Y. Yang, J. Zheng, W. Hua and G. Chen, Mater. Chem. Phys., 2009, 114, 319-322.

14 S. Choi, S. Cho, J. Lee, D.-Y. Jeong and H. Kim, Met. Mater. Int., 2015, 21, 686-691.

15 J. M. Park, K. H. Park, E. S. Park, S.-M. Hong, S. Y. Kim, S. S. Jee, E. S. Lee, S. J. Kim, K. B. Kim and D. H. Kim, Metall. Mater. Trans. A, 2015, 46, 2443-2448.

16 G. Schubert, F. Huster and P. Fath, Sol. Energy Mater. Sol. Cells, 2006, 90, 3399-3406.

17 K.-K. Hong, S.-B. Cho, J. S. You, J.-W. Jeong, S.-M. Bea and J.-Y. Huh, Sol. Energy Mater. Sol. Cells, 2009, 93, 898-904.

18 X.-X. Pi, X.-H. Cao, Z.-X. Fu, L. Zhang, P.-D. Han, L.-X. Wang and Q.-T. Zhang, Acta Metall. Sin., 2015, 28, 223-229.

19 J. H. Yi, H. Y. Koo, J. H. Kim, Y. N. Ko, Y. J. Hong, Y. C. Kang and H. M. Lee, J. Alloys Compd., 2011, 509, 6325-6331.

20 D. Seo, S. Park and J. Lee, Curr. Appl. Phys., 2009, 9, S72-S74.

21 D. Kim, S. Hwang and H. Kim, J. Korean Phys. Soc., 2009, 55, 1046-1050.

22 S. H. Park, D. S. Seo and J. K. Lee, J. Nanosci. Nanotechnol., 2008, 8, 5331-5336.

23 S. J. Jeon, S. M. Koo and S. Am Hwang, Sol. Energy Mater. Sol. Cells, 2009, 93, 1103-1109.

24 J. H. Kim, H. Y. Koo, Y. N. Ko and Y. C. Kang, J. Alloys Compd., 2010, 497, 259-266.
25 J. Jiang, Y. He, Z. Zhang, J. Wei and L. Li, J. Alloys Compd., 2016, 689, 662-668.

26 J. D. Fields, M. I. Ahmad, V. L. Pool, J. Yu, D. G. Van Campen, P. A. Parilla, M. F. Toney and M. F. Van Hest, Nat. Commun., 2016, 7, 11143-11150.

27 E. R. Shaaban, M. Shapaan and Y. B. Saddeek, J. Phys.: Condens. Matter, 2008, 20, 155108.

28 Y. Cheng, H. Xiao, W. Guo and W. Guo, Thermochim. Acta, 2006, 444, 173-178.

29 Y. Zhang, Y. Yang, Y. Ou, W. Hua, J. Zheng and G. Chen, J. Am. Ceram. Soc., 2009, 92, 1881-1883.

30 X. Zhu, C. Mai and M. Li, J. Non-Cryst. Solids, 2014, 388, 5561.

31 E. Kamitsos, A. Patsis, M. Karakassides and G. D. Chryssikos, J. Non-Cryst. Solids, 1990, 126, 52-67.

32 A. Hassan, L. Börjesson and L. Torell, J. Non-Cryst. Solids, 1994, 172, 154-160.

33 Y. Cheng, H. Xiao and W. Guo, Mater. Sci. Eng., A, 2008, 480, 56-61.

34 C.-H. Lin, S.-Y. Tsai, S.-P. Hsu and M.-H. Hsieh, Sol. Energy Mater. Sol. Cells, 2008, 92, 1011-1015.

35 M. M. Hilali, S. Sridharan, C. Khadilkar, A. Shaikh, A. Rohatgi and S. Kim, J. Electron. Mater., 2006, 35, 20412047.

36 B. Sopori, J. Rand, T. Saitoh, R. Sinton, M. Stavola, D. Swanson, T. Tan, E. Weber, J. Werner and M. Al-Jassim, 13th Workshop on Crystalline Silicon Solar Cell Materials and Processes: Extended Abstracts and Papers, National Renewable Energy Laboratory (NREL), Golden, CO., 2003.

37 Y. Tai, G. Zheng, H. Wang, H. Wang and J. Bai, RSC Adv., 2015, 5, 92515-92521. 